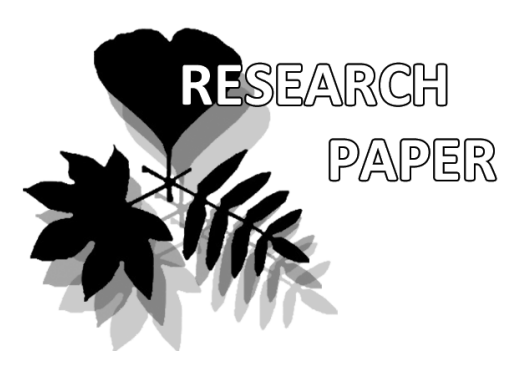

\title{
Invasive species in Kamchatka: distribution and communities
}

\author{
Larisa M. Abramova ${ }^{1}$, Olga A. Chernyagina ${ }^{2}$, \\ Elizaveta A. Devyatova ${ }^{3 *}$
}

Larisa M. Abramova

e-mail: abramova.lm@mail.ru

Olga A. Chernyagina ${ }^{2}$

e-mail:kamchatika@mail.ru

Elizaveta A. Devyatova ${ }^{3 *}$

e-mail: devyatovaea@mail.ru

${ }^{1}$ Botanical Garden-Institute of the Ufa Scientific Centre of the Russian Academy of Sciences, Ufa, 450080, Russia

${ }^{2}$ Kamchatka Branch of Pacific Institute of Geography FEB RAS, PetropavlovskKamchatskii, 683000, Russia

${ }^{3}$ Vitus Bering Kamchatka State University, Petropavlovsk- Kamchatskii, 683032, Russia

* corresponding author

Manuscript received: 25.09.2016

Review completed: 17.04 .2017

Accepted for publication: 05.05.2017

Published online: 07.06.2017

\begin{abstract}
A B S T R A C T
This paper presents information about the distribution of invasive plant species in the Kamchatka Peninsula and the communities formed by these species in the urban areas. Some of these species are from the "black list" of invasive plants of Russia and some plants are usual for central Russia. These species were introduced to the Kamchatka Peninsula and actively spread over the urban area in recent years. We assign communities with the dominance of the species under study to 2 classes of vegetation: Galio-Urticetea and Molinio-Arrhenatheretea. The paper presents the prodromus of vegetation communities with the dominance of the invasive species and a brief description of the syntaxa. The invasive species successfully invade synanthropic habitats, including the natural communities. It is necessary to observe their ecological status and find ways to prevent their further spread in the Kamchatskii Krai.
\end{abstract}

K e y w o r d s : Kamchatka, synanthropic vegetation, alien plants, invasive species, invasion focal points

\section{P Е 3 Ю M E}

Абрамова М.М., Чернягина О.А., Аевятова Е.А. Инвазионные виды Камчатки: распространение и сообщества. В статье представ ены свеАения о распространении инвазионных видов растений на полуострове Камчатка и их сообществах, формирующихся в населенных пунктах. Среди них есть как виды из «черного списка» инвазионных растений России, так и обычные Аля средней полосы России растения, являющиеся заносными на Камчатке и активно заселяющие городскую территорию в последние годы. Описанные сообщества с доминированием данных видов охарактеризованы как дериватные и отнесены к 2 классам растительности: Galio-Urticetea и Molinio-Arrhenatheretea. Представлен продромус растительных сообществ с Аоминированием изучаемых видов и дана краткая характеристика выделенных синтаксонов. Инвазионные вилы не только успешно распространяются по синантропным местообитаниям, но и имеют тенденцию к внеАрению в естественные сообщества, поэтому в дальнейшем необходим мониторинг их состояния, а также поиск путей слерживания их дальнейшего распространения по Камчатскому краю.

К $\mathbf{\Lambda}$ ю ч е в ы е с $\mathbf{\Lambda}$ о в а: Камчатка, синантропная растительность, заносные виды, инвазионные виды, очаги инвазии
The previous examination of synanthropic flora of the Kamchatka was only fragmentary and now requires an overall inventory. Some alien species actively spread due to the development of housing construction, road networks and transport systems (Devyatova et al. 2015). Among them there are problematic invasive species. These species produce numerous progenies, spread over the region and often invade into natural habitats. We started the examination of the urban areas of Petropavlovsk-Kamchatskiy and other settlements in 2012. This paper presents data concerning the communities formed by some alien species: Heracleum sosnowskyi Manden., Impatiens glandulifera Royle, Symphytum caucasicum Bieb., Lupinus polyphyllus Lindl., Reynoutria sachalinensis (Fr. Schmidt) Nakai, Tussilago farfara L., Vicia cracca L.,
Arctium tomentosum Mill. They include both species of Russia's invasive plants "Black List" (Vinogradova et al. 2015) and the plants of the temperate zone of Russia.

\section{MATERIAL AND METHODS}

The Kamchatskii Krai is a federal entity of the Russian Federation. It occupies the territory of the Kamchatka Peninsula with the continental adjacent part of the mainland, Karaginsky island and Commander Islands. The administrative center is the city of Petropavlovsk-Kamchatskiy; with a population of about 180000 people.

Petropavlovsk-Kamchatskiy stretches along $25 \mathrm{~km}$ of the eastern coast of Avacha Bay which is a part of the Pacific Ocean $\left(53^{\circ} 01^{\prime} \mathrm{N} 158^{\circ} 39^{\prime} \mathrm{E}\right)$. The city has a strong 
mountainous relief ranging from 0 to $380 \mathrm{~m}$ a.s.l. The territory of Petropavlovsk-Kamchatskiy covers the eastern coastal sub-region and has a maritime climate with excess humidity. Intensive cyclonic activity is the basic climateforming process especially during autumn and winter (Kondratyuk 1983). The average annual temperature is $+2.1^{\circ} \mathrm{C}$. The average daily temperature in January is $-8.7^{\circ} \mathrm{C}$, in August $-+14^{\circ} \mathrm{C}$. The active growth period of vegetation lasts from the 22nd of May to the 14th of October. The average annual precipitation is $1300 \mathrm{~mm}$ with $56 \%$ during winter. The number of days with snow cover is 177 with an average maximum height of snow cover of $136 \mathrm{~cm}$.

Since 2012, we observed the territories of PetropavlovskKamchatskiy, Yelizovo, Vilyuchinsk and 9 villages: Paratunka, Apacha, Sosnovka, Esso, Anavgay, Klyuchi, Ivashka, Palana and Ossora.

For the investigation of Petropavlovsk-Kamchatskiy territory, we made geobotanical survey of synanthropic communities formed by alien species and obtained 66 relevés. We estimated the abundance of species according to the Braun-Blanquet scale as follows: $\mathrm{r}-$ the occurrences of species are single, the cover-abundance rating is insignificant; + - the species occurs rarely, the cover-abundance rating is low; $1-$ the number of the species is high but the cover-abundance rating is low, up to $5 \% ; 2$ - the cover is $5-25 \%$; 3 - the cover is $25-50 \%$; 4 - the cover is $50-75 \%$; 5 - the cover is more than $75 \%$. The constancy of species in the communities was estimated according to five-grade scale: I - 1-20 \%; II - 21-40 \%; III - 41-60\%; IV - 61$80 \% ; \mathrm{V}-81-100 \%$.

For plant identification we used "A field guide to vascular plants of Kamchatka region" (1981), "Vascular plants of the Soviet Far East" (Kharkevich 1985-1996). The taxonomic names follow Cherepanov (1995).

We preceded the relevés in accordance with the principles of ecological-floristic classification (Braun-Blanquet 1964) with the application of the deductive method of Kopečky-Hejny (Kopečky 1974). This allowed us to classify depauperate, seral and derivative (replacement) communities with the participation of alien species. This method has been often used in Russia in recent years for the classification of various communities with invasive plant species (Bulokhov et al. 2008, 2011, Abramova 2011a, 2015, Golovanov \& Abramova 2012, Abramova et al. 2013, Panasenko et al. 2013, Arepjeva 2015).

We included relevés into the database of TURBOVEG (Hennekens 1995) and processed with an aid of the Juice program (Tichy 2002).

\section{RESULTS}

As a result of the investigation 8 alien species are found in the city of Petropavlovsk-Kamchatskiy, which can be considered invasive for the Kamchatka region in the whole. We studied communities with the dominance of these species and classified them as derivative i.e. replacement communities. The communities belong to 2 classes: the class of nitrophilic communities of shady habitats Galio-Urticetea and the class of meadow vegetation Molinio-Arrhenatheretea.
We present the prodromus of vegetation communities with the dominance of the invasive species and short description of the revealed syntaxa below.

Class GALIO-URTICETEA Passarge ex Kopecký 1969

Derivative communities:

- Heracleum sosnowskyi [Galio-Urticetea]

- Reynoutria sachalinensis [Galio-Urticetea]

- Symphytum caucasicum [Galio-Urticetea]

- Tussilago farfara [Galio-Urticetea/Polygono arenastri-Poëtea annuae]

- Arctium tomentosum [Galio-Urticetea]

- Impatiens glandulifera [Galio-Urticetea]

Class MOLINIO-ARRHENATHERETEA R.Tx 1937

Order Arrhenatreretalia R.Tx 1937

Alliance Cynosurion R.Tx 1947

Derivative communities:

- Lupinus polyphyllus [Molinio-Arrhenatheretea]

- Vicia cracca [Molinio-Arrhenatheretea]

\section{Derivate community Heracleum sosnowskyi \\ [Galio-Urticetea] (Table 1, cluster 1)}

Sosnovsky hogweed is one of the most aggressive invasive species of the European part of Russia (Vinogradova et al. 2010, 2015). It is one of priority targets for research and control (Dgebuadze 2014), because it is a serious threat to ecosystems.

Initially, Sosnowsky hogweed was introduced into Kamchatka as a silage crop. In 1985 thickets of H. sosnowskyi appeared on the experimental plots of Kamchatka Agricultural Research Station in Sosnovka. Moreover, H. sosnowskyi nowadays covers extensive areas of lawns and grows on heated soils near the thermal pools, wells and pipelines of the Paratunka resort area in Yelizovsky district. We recorded the focal point of invasion of Sosnovsky hogweed in Petropavlovsk-Kamchatskiy in 2010 near the pipeline in "Seroglazka" district (Chernyagina \& Strecker 2012). The plants reach a height of 3.5-4.0 m, have good vitality and abundant fruiting. Nowadays we note an active expansion of Sosnovsky hogweed about the territory of the city. The species forms monodominant thickets of $2-3 \mathrm{~m}$ height in the district of "Seroglazka", "The 6th kilometer", "The 4th kilometer", "Horizon" spreading across wastelands and along road-sides (Abramova et al. 2014). Native species Heracleum lanatum Michx. do not achieve such a height and biomass in similar habitats. It is possible that in the urban area $H$. sosnowskyi could eventually displace the native $H$. lanatum.

Composition. H. sosnowskyi dominates in the community and forms practically monodominant thickets. Species of the class Galio-Urticetea mainly occur in the community. The number of species is from 5 to 12 , with the average species abundance of 8 species.

Structure. The community has a 2-layer structure. H. sosnowskyi plants form the upper layer (from 1 to $3 \mathrm{~m}$ ), while other plants occupy the lower layer and have a small height (up to $30 \mathrm{~cm}$ ). The total cover is $100 \%$.

Ecology. We observed the community on well-lit slopes of southern exposure, near heating pipelines, along road-sides (Fig. 1A). 
Table 1. Synoptic table of the communities distinguished. The presence of species is given as constancy class. Cluster numbers: 1 - Derivative comm. Heracleum sosnowskyi $[G a-$ lio-Urticetea]; 2 - Derivative comm. Reynoutria sachalinensis [Galio-Urticetea]; 3 - Derivative comm. Symphytum caucasicum [Galio-Urticetea]; 4 - Derivative comm. Tussilago farfara [GalioUrticetea/Polygono arenastri-Poëtea annuae]; 5 - Derivative comm. Arctium tomentosum [Galio-Urticetea]; 6 - Derivative comm. Impatiens glandulifera [Galio-Urticeted]; 7 - Derivative comm. Lupinus polyphyllus [Molinio-Arrbenatheretea]; 8 - Derivative comm. Vicia cracca [Molinio-Arrhenatheretea].

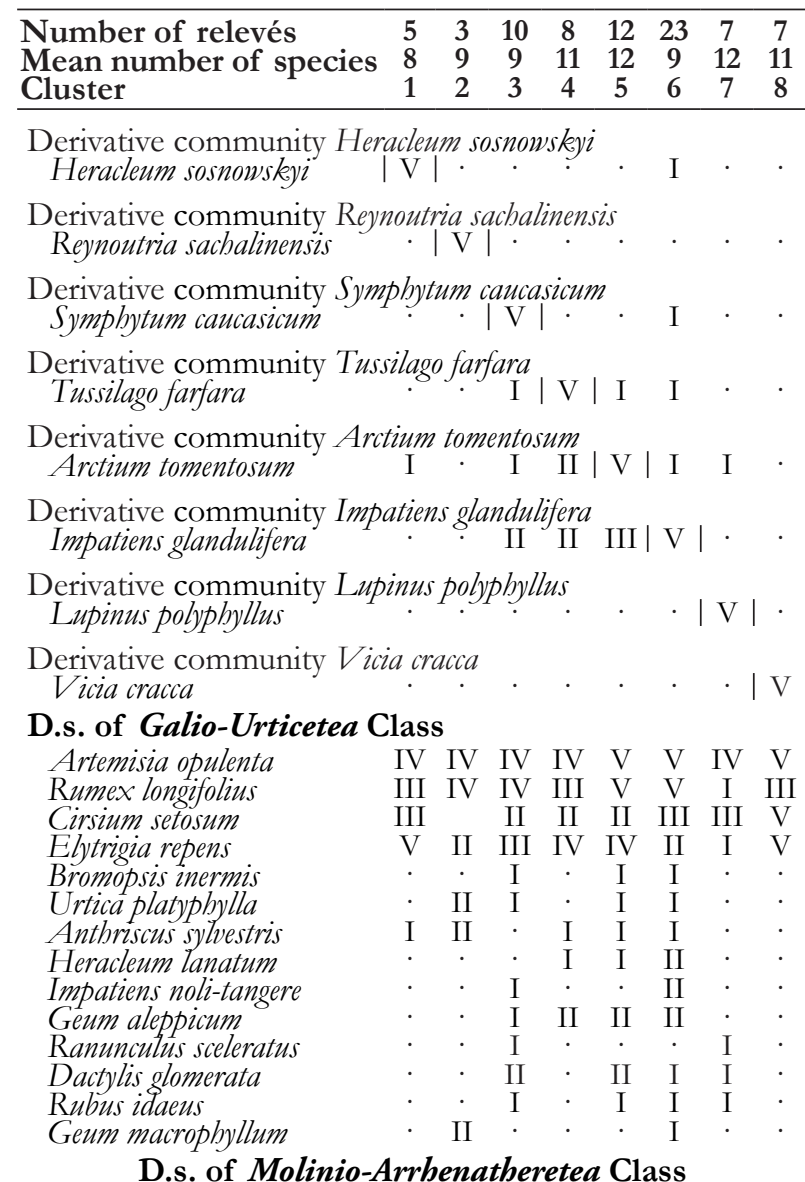

$\begin{array}{llccccccc}\text { Ranunculus repens } & \cdot & \cdot & \cdot & \text { II } & \cdot & \text { I } & \text {. } & \text { II } \\ \text { Taraxacum officinale } & \text { I } & \text { IV } & \text { III } & \text { V } & \text { V } & \text { IV } & \text { V } & \text { V }\end{array}$

\section{Derivate community Reynoutria sachalinensis \\ [Galio-Urticetea] (Table 1, cluster 2)}

Giant knotweed is a species of the "black list" (Vinogradova et al. 2010, 2015). This aggressive neophyte spreads in various areas of Russia including the Far East (Fukuda et al. 2014). It is a common ornamental plant in PetropavlovskKamchatskiy and suburbs, and villages of Yelizovsky district (Paratunka, Malki). The plant is known in Kamchatka for at least 25 years. Now R. sachalinensis spreads in lawns, ruins and dumps. We observed active seed reproduction in Paratunka.

Composition. The species is used in residential areas of the city with decorative purposes, for creating hedges. It survives for a long time in the areas of cultivation, from which wild thickets spread. In the wastelands of Petropavlovsk-Kamchatskiy (the city-centre, "Seroglazka") it forms dense monodominant thickets up to $3 \mathrm{~m}$ in height
Table 1. Continued

\begin{tabular}{|c|c|c|c|c|c|c|c|c|}
\hline Cluster & 1 & 2 & 3 & 4 & 5 & 6 & 7 & 8 \\
\hline Hordeum brachyantherum & $\mathrm{I}$ & & $\mathrm{I}$ & & II & II & & \\
\hline Trifolium pratense & & II & & ; & I & $\cdot$ & III & \\
\hline Amoria repens & II & & . & I & I & & II & III \\
\hline Agrostis gigantea. & & II & & & I & I & I & \\
\hline Achillea millefolium & . & II & I & I & I & & III & III \\
\hline Poa pratensis & & & I & & II & I & III & \\
\hline Phleum pratense & II & II & & II & II & I & II & III \\
\hline Poa angustifolia & & IV & & & & II & $\mathrm{I}$ & \\
\hline Leontodon autumnalis & . & & . & II & I & & & II \\
\hline Poa palustris & . & & & & & I & I & \\
\hline Gatium boreale & · & $\cdot$ & I & . & . & & & - \\
\hline Agrostis tenuis & . & . & I & . & . & I & I & . \\
\hline Fimbripetalum radians & . & . & & II & . & & & \\
\hline Geranium eriantbum & . & . & . & & I & . & II & . \\
\hline Epilobium glandulosum & . & & . & . & I & . & . & . \\
\hline Agrostis stolonifera & & II & & I & & I & . & \\
\hline \multicolumn{9}{|c|}{ D.s. of Stellarietea mediae Class } \\
\hline Chenopodium album & I & & I & II & II & I & . & \\
\hline Galeopsis bifida & & & $\mathrm{I}$ & I & I & I & . & . \\
\hline Stellaria media & II & IV & III & II & II & II & . & . \\
\hline Capsella bursa-pastoris & & II & II & II & II & II & . & \\
\hline Trpleurospermum perforatum & $\cdot$ & & & & I & $\mathrm{I}$ & is & \\
\hline Oberna behen & . & - & . & . & $\mathrm{I}$ & & I & II \\
\hline Brassica campestris & . & . & . & I & I & . & & \\
\hline Sonchus arvensis & . & . & . & I & & . & . & \\
\hline Centaurea cyanus & . & II & & . & . & . & I & \\
\hline \multicolumn{9}{|c|}{ D.s. of Polygono arenastri-Pö̈tea annuae Class } \\
\hline Polygonum aviculare & I & & I & I & III & I & . & . \\
\hline Lepidotheca suaveolens & II & II & II & II & II & I & & \\
\hline Plantago major & III & II & II & IV & IV & II & & III \\
\hline Poa aпnua & I & & I & II & II & II & . & \\
\hline \multicolumn{9}{|l|}{ Remaining species } \\
\hline Leymus mollis & I & . & & & & & II & \\
\hline Poa species & & II & I & II & I & & & III \\
\hline Calamagrostis langsdorffii & . & & & & I & . & III & \\
\hline Aruncus dioicus & . & . & I & & & & I & \\
\hline Rosa amblyotis & . & . & I & & . & I & II & II \\
\hline Equisetum arvense & . & - & . & II & . & . & II & \\
\hline Cacalia hastata & . & . & I & & . & . & I & \\
\hline
\end{tabular}

Note. Beside above mentioned, the following species were observed: Rumex acetosella 4 (I), Barbarea orthoceras 4 (II), Salix udensis 6 (I), Ranunculus acris 6 (I), Carum carvi 6 (I), Alnus birsuta 7 (I); Ptarmica camtschatica 7 (I); Aquilegia vulgaris 7 (I); Grossularia uva-crispa 7 (I); Hesperis matronalis 7 (I); Myosotis arvensis 7 (I); Pedicularis resupinata 7 (I); Lilium debile 7 (I), Chamaenerion angustifolium 7 (I), Thalictrum minus 7 (II), Rhinanthus minor 7 (II), Pleurospermum uralense 8 (I), Lagedium sibiricum 8 (I).

(Abramova et al. 2014). Species of the class Galio-Urticetea (Artemisia opulenta, Rumex longifolius) and the class MolinioArrbenatheretea (Taraxacum officinale, Poa angustifolia) occur in the community with great constancy. The quantity of species in the community is $7-11$, with an average of 9 species.

Structure. The community has a 2-layer structure. The sprouts of Reynoutria sachalinensis form the upper layer (from 1 to 3 meters high). Also there are rare sprouts of Artemisia opulenta, Rumex longifolius in this layer. Low-growing species occur in the lower layer (Taraxacum officinale, Stellaria media). The total cover is $100 \%$.

Ecology. Yards, front gardens, abandoned kitchen gardens, lawns, often in the shade (Fig. 1B).

\section{Derivate community Symphytum caucasicum}

[Galio-Urticetea] (Table 1, cluster 3)

Blue comfrey, or Caucasian comfrey, is a species of "Black Book of the flora of Russia's Temperate Zone" (Vi- 

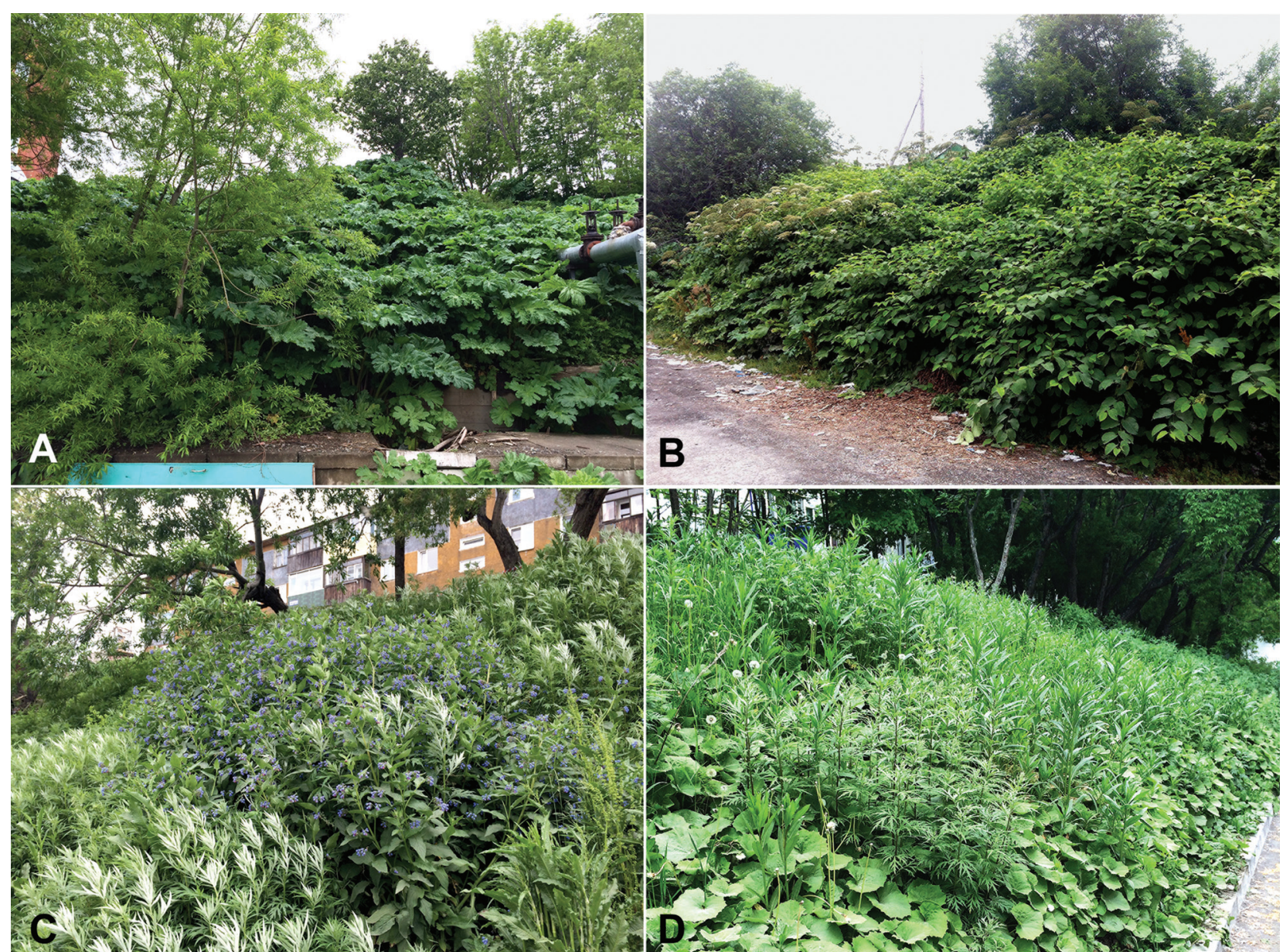

II)

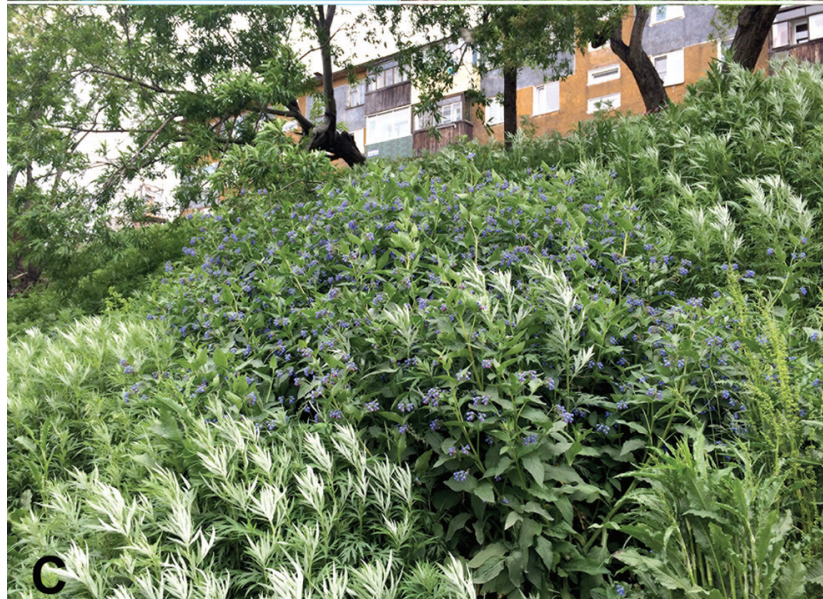

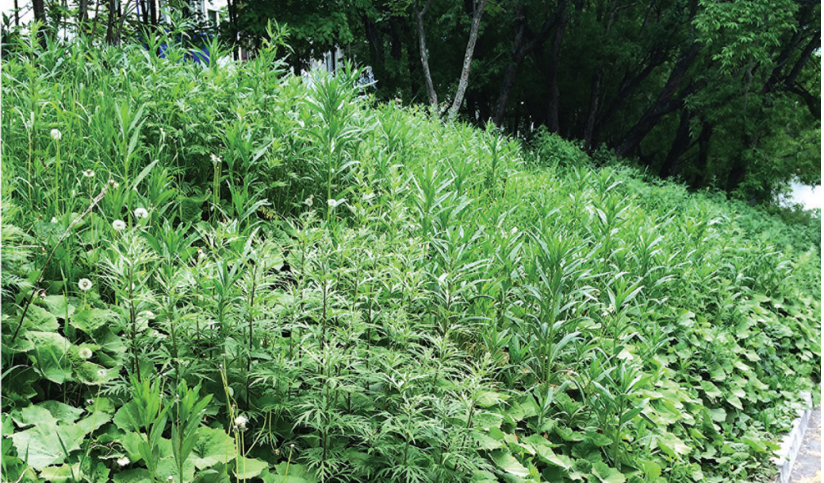

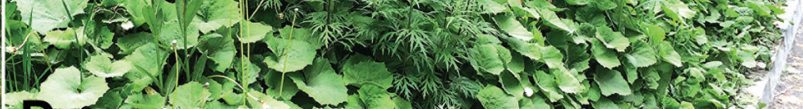

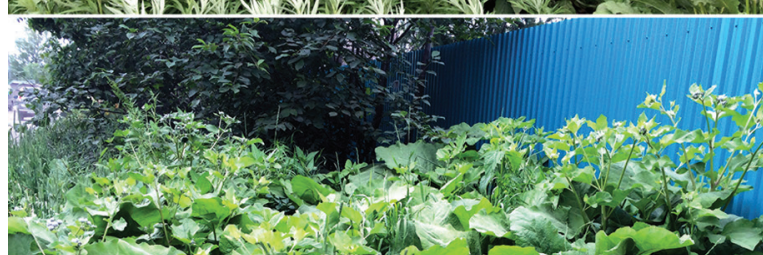

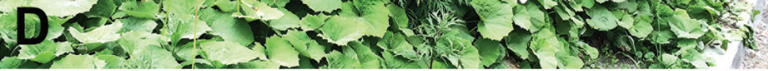

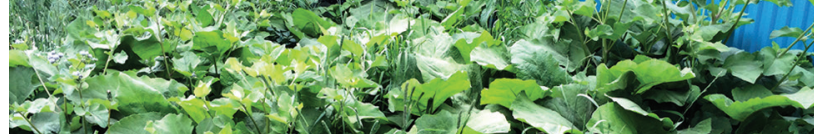
(D)

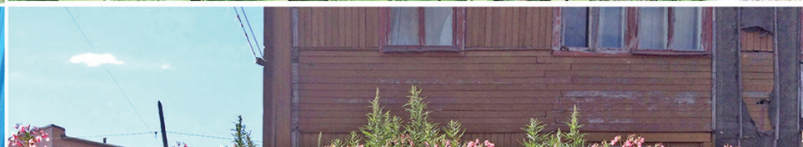

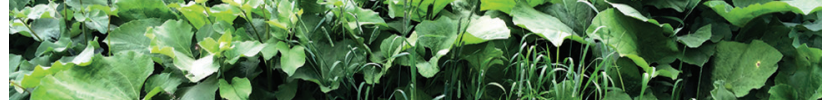
(2)

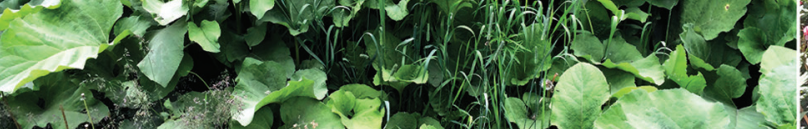

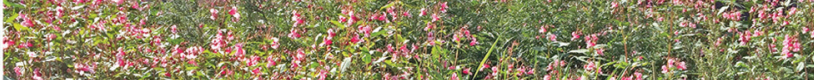

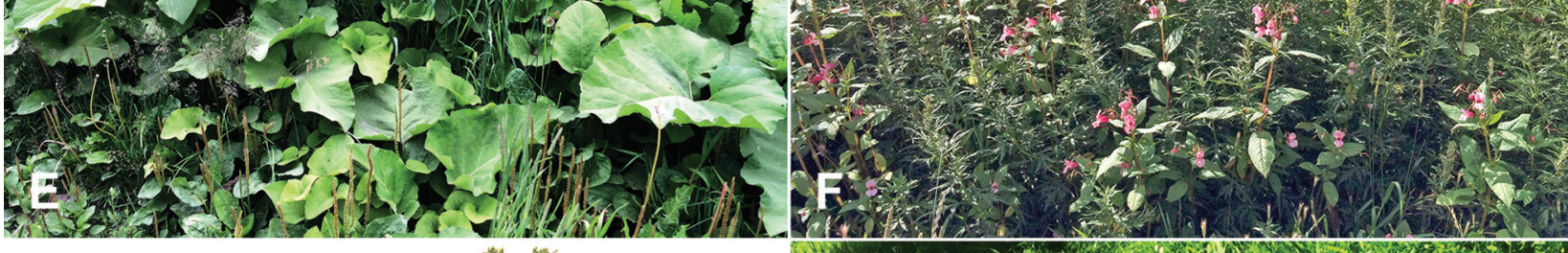

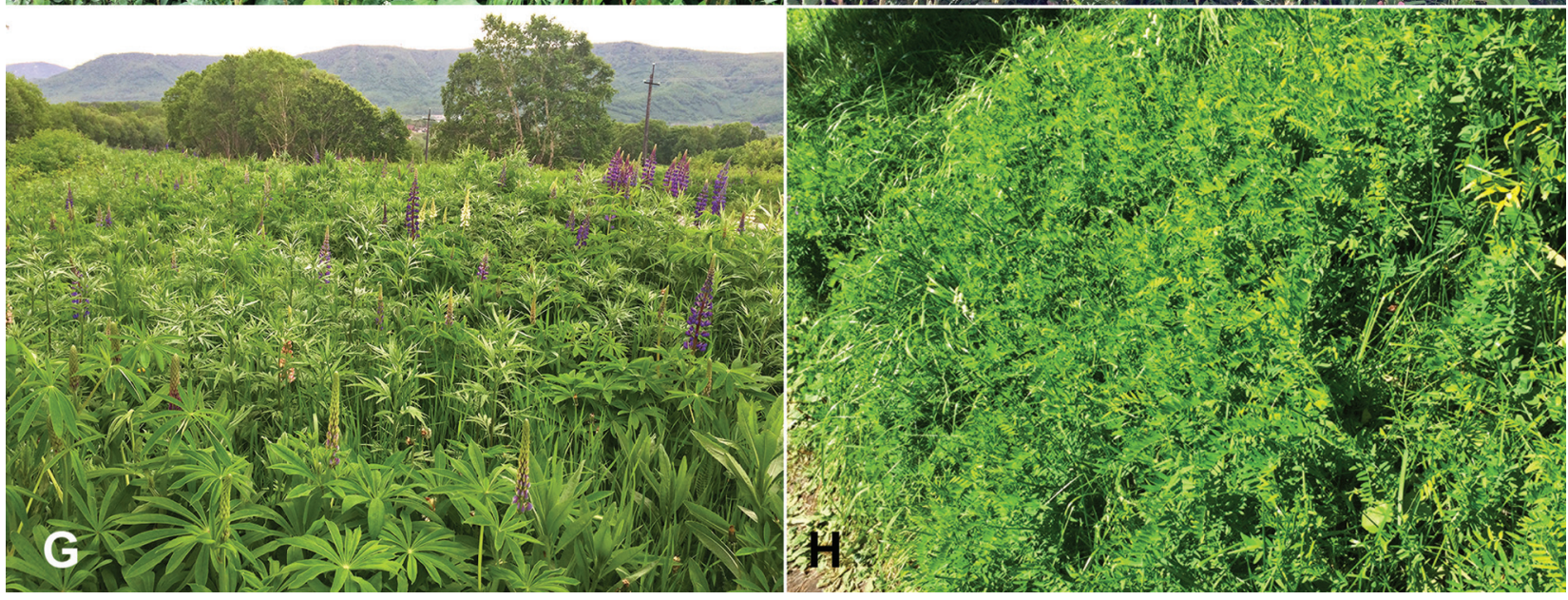


nogradova et al. 2010). The plant is used as an ornamental in the gardens of apartment buildings and private houses. S. caucasicum grows wild in lawns, dumps, and spreads in hillsides and meadows. The plant begins to grow under the winter snow cover and has early flowering pattern. It is commonly found not only in the city of PetropavlovskKamchatskiy but also in Esso (Bystrinsky district).

Composition. The species dominates in the communities. In Petropavlovsk-Kamchatskiy, it is cultivated on the sites near cottage-houses and in the front gardens of blocks of flats as an unpretentious plant which is easy to control. Species of the class Galio-Urticetea (Artemisia opulenta, Rumex longifolius) often occur in the community. The species abundance is from 4 to 16 species, on average 9 species.

Structure. Community has mainly a two-layer structure. In some cases there is a shrub layer with Rosa amblyotis or Rubus idaeus. In the upper layer the comfrey dominates. Also sprouts of Artemisia opulenta, Rumex longifolius can be observed. In the lower layer Stellaria media, Taraxacum officinale, Plantago major and other low-growing plants prevail. The total cover is $100 \%$.

Ecology. The community occupies the plots near the walls of blocks of flats, front gardens and often grows in the shade. It also occurs along the slopes of the hills in residential areas of the city (Fig. 1C).

\section{Derivate community Tussilago farfara}

[Galio-Urticetea/Polygono arenastri-Poëtea annuae]

(Table 1, cluster 4)

Coltsfoot in central Russia is an ordinary native ruderal species. In Kamchatka it is a progressive invasive plant. Plant seeds were brought for cultivation in 1970-80-s. T. farfara soon became a weed observed in gardens and flowerbeds. The species became common in Petropavlovsk-Kamchatskiy during last 10 years. Plants begin to grow and form flower buds under the winter snow cover. T. farfara now is widespread in Yelizovsky district, Esso (Bistrinsky district) and Palana (Tigilsky district of Koryak Okrug).

Composition. T. farfara dominates in the community. It grows in disturbed habitats (refuse piles of ground, new roadsides) (Chernyagina et al. 2013). Species of the class Galio-Urticetea (Artemisia opulenta, Elytrigia repens) mainly form the community. Plantago major and Taraxacum officinale occur frequently. The number of species in the community is from 9 to 16 with an average species abundance of 11 species.

Structure. One layer which is represented by low-growing plants. The average height of the herbage is $30 \mathrm{~cm}$. The total cover is $70-100 \%$.

Ecology. The community occupies open sites: lawns, yards, slopes of southern exposure, roadsides (Fig. 1D).

\section{Derivate community Arctium tomentosum}

[Galio-Urticetea] (Table 1, cluster 5)

Cotton burdock is a common species of ruderal habitats in the temperate zone of Russia. It is an introduced species for Kamchatka. A. tomentosum forms replacement communities on the lawns and in the city yards. First found in 1989 in Klyuchi in the Ust-Kamchatsk district, the species established to the south due to road improvements. Nowadays it occupies lawns, dumps and yards. The plant has a good vitality and abundant fruiting. It actively spreads in Petropavlovsk-Kamchatskiy and Yelizovo, villages of Yelizovsky district, Klyuchi (Ust-Kamchatsk district), and Palana (Tigilsky district of Koryak Okrug).

Composition. A. tomentosum is the dominant species of the community. Species of the class Galio-Urticetea (Artemisia opulenta, Rumex longifolius, Elytrigia repens) occur with high constancy. The intensity of cotton burdock spreading increased in recent years. It is facilitated by regular lawn mowing in the city and is further assisted with the appearance of vacant habitats in eroded sites (Chernyagina et al. 2013). The species number is $7-15$; the average is 11 .

Structure. The structure of the community depends on the nature of the occupied habitats. In the city yards the community has a two-layer structure. The upper layer which is $100-110 \mathrm{~cm}$ high is formed by the sprouts of Arctium tomentosum, Rumex longifolius and Artemisia opulenta.

Low-growing plants, such as Stellaria media, Poa annua, Plantago major form the lower layer $(15-20 \mathrm{~cm})$. On the lawns and along the roadsides the height of the herb layer depends on the frequency of mowing procedures and constitutes $20-30 \mathrm{~cm}$. In this case the community has one layer. The total cover is 70-100\%.

Ecology. The community occupies open sites: yards, roadsides, lawns (Fig. 1E).

\section{Derivate community Impatiens glandulifera \\ [Galio-Urticetea] (Table 1, cluster 6)}

Ornamental jewelweed is another aggressive species from the "Black Book" and "black-list" of the flora of Russia (Vinogradova et al. 2010, 2015). As in other regions of Russia, I. glandulifera was used as an ornamental garden plant. It grows in wet areas, moist roadsides, osier-beds, streams and competes with the native I. noli-tangere $\mathrm{L}$. It has good vitality and abundant fruiting. We commonly find the plant in the settlements of southern and central Kamchat$\mathrm{ka}$, and in Ivashka (Karaginsky district of the Koryak Okrug).

Composition. This invasive species dominates in the community. It becomes invasive, spreading from front gardens of apartment blocks and single detached houses and penetrates the natural habitats. Species of the class GalioUrticetea (Artemisia opulenta, Rumex longifolius) occur with high constancy. The species number is $7-15$, average 10 .

Structure. The community has one-layer or two-layer structure. The upper layer which is up to $80 \mathrm{~cm}$ in height and represented by the sprouts of Impatiens glandulifera, Artemisia opulenta, Cirsium setosum. The lower layer which is up to $30-40 \mathrm{~cm}$ in height and formed by Taraxacum officinale, Stellaria media. The total cover is $70-100 \%$.

Figure 1 Derivative communities of invasive alien plants in Kamchatka. A - Heracleum sosnowskyi; B - Reynoutria sachalinensis; C - Symphytum caucasicum; D - Tussilago farfara; E - Arctium tomentosum; F - Impatiens glandulifera; G - Lupinus polyphyllus; H - Vicia cracca. 
Ecology. The community occurs on shady slopes in the residential areas, along streams, on well-lit sites: abandoned front-gardens, yards, along the roads (Fig. 1F).

\section{Derivate community Lupinus polyphyllus}

\section{[Molinio-Arrhenatheretea] (Table 1, cluster 7)}

Bigleaf lupine is an alien species from the "Black Book of the Flora of Russia's Temperate Zone" (Vinogradova et al. 2010) and the "black-list" (Vinogradova 2015). For a long time it was cultivated in Petropavlovsk-Kamchatskiy as an ornamental plant. Over past years we observed the spread of L. polyphyllus in osier-beds and meadows along roads. It has active seed reproduction. The species is common in Petropavlovsk-Kamchatskiy and Yelizovsky districts. The lupine commonly occurs in the city near the foundations of multi-storey buildings, on untended lawns, in weedy places, in abandoned kitchen-gardens and plots. The species is a "refugee" from the cultivated plants group. It starts blooming in July on the slopes of city hills (in the "Seroglazka" and "Horizon" districts) and along Khalaktyrskoye Highway.

Composition. Lupine is the dominant in the community. Meadow species of the class Molinio-Arrenatheretea ( $\mathrm{Ta}$ raxacum officinale, Poa pratensis, Achillea millefonium) and the class Galio-Urticetea (Artemisia opulenta, Cirsium setosum) occur with high constancy. The number of species in the community is $6-18$, the average is 12 .

Structure. There is mainly one layer. In some cases there is a shrub layer formed by Rosa amblyotis, Grossularia uva-crispa or Rubus idaeus. The average height is $90 \mathrm{~cm}$. The total cover is $100 \%$. $1 G)$.

Ecology. Open slopes of hills, roadsides, yards (Fig.

\section{Derivate community Vicia cracca}

\section{[Molinio-Arrhenatheretea] (Table 1, cluster 8)}

Bird vetch is one more common meadow species of the Temperate zone in Russia. The plant became an invasive species for Kamchatka. Nowadays we observe the intensive spread of the species in Kamchatka (Chernyagina \& Strecker 2012). In Alaska $V$. cracca is a species with a high invasive rank. The plant is known in the Kamchatka Peninsula since the early 20th century. Komarov (1954) first recorded $V$. cracca in Ust-Bolsheretsky district as a weed of field crops. Today the species is widespread over the territory of Kamchatka.

Composition. Vicia cracca determines the appearance of the community. Species of the alliance Cynosurion and the class Molinio-Arrhenatheretea (Taraxacum officinale, Phleum pratense, Amoria repens), as well as of the class Galio-Urticetea (Cirsium setosum, Elytrigia repens) occur with high constancy. The species composition consists of from 7 to 14 species; the average number is 11 species.

Structure. The community mostly possesses a twolayer structure. The main layer is represented by the sprouts of Artemisia opulenta, Elytrigia repens, Cirsium setosum, Rumex longifolius, which are densely entangled by $V$. cracca. The second layer which is up to $20 \mathrm{~cm}$ in height is represented by low-growing plants, such as Plantago major, Amoria repens, Taraxacum officinale. The height of the herbage varies from 20 to $90 \mathrm{~cm}$. The total cover is from 60 to $100 \%$.
Ecology. The community occurs on well-lit sites: lawns, roadsides, yards (Fig. 1H).

\section{DISCUSSION}

Nowadays, the problem of alien species invasion is a part of the global change of ecosystems. The world scientific communities have widely discussed the impact of the alien species on the natural communities and their interaction with the native species (Johnstone 1986, Biological invasions... 1990, Thompson 1997, Tilman 1997, Falinski 1998, Lonsdale 1999, Parker et al. 1999, Richardson et al. 2000, Kowarik 2003, Didham et al. 2005, Hulme 2007, Pyšek et al. 2012, Anačkov et al. 2013). Alien plants are able to compete with the native species and even displace them from the natural communities. This causes dystrophication and simplification of phytocenoses structure by breaking the ecological ties in the community. Understanding the processes of invasion is important for the development of effective ways of controlling invasive species and the damage they can do to native species and ecosystems (Gurevitch $\&$ Padilla 2004). The explosive expansion of alien species may be caused by anthropogenic transformation of habitats, climate change, absence of pests and pathogens etc. Alien plants often form monodominant communities and hybridize with native species. Besides, alien plants perform the role of new host-plants for parasites and pathogenic agents (involving stranger infections) and as well they can exert a specific influence on pollinating insects (King \& Sargent 2012, Engelkes \& Mills 2013). Comparing alien floras and invasive species of different regions is necessary for understanding general patterns of invasion process (Pysek et al. 1998, 2004).

In Russia researchers study the processes of invasion in various regions (Abramova 2011b, 2012, Abramova \& Anufriev 2008, Bulokhov et al. 2011, Silaeva 2011, Tretiyakova 2011, Panasenko et al. 2013, Ebel 2014) and publish "Black Lists" (Vinogradova et al. 2010, 2011, Ageeva \& Silaeva 2012, Tremasova et al. 2012, Panasenko et al. 2012, Sagalaev 2013, Starodubtseva et al. 2014, Baranova \& Bralgina 2015). However, the investigation of invasive process in the northern regions of the Russian Far East is still one of the blank spaces.

The weed flora of the Kamchatka was not previously sufficiently studied. For the first time Komarov (1954) investigated alien flora during his travel within Kamchatka in 1908-1909. Fedorchenko (1971) presented further data of weed flora of the region. In 1973 Ulyanova $(1976,1982)$ examined weed infestation of Kamchatka's agricultural crops. She noticed that the Kamchatka weed flora was rather poor in comparison with other regions of the Far East and the species composition of weed plants was not stable and depended on the introduction of alien plans. She revealed only 75 species. In recent years Chernyagina studied alien flora and invasive plant species of the region (Chernyagina et al. 2012, 2013, 2014). She revealed that in Kamchatka weed plant species frequently expand in the areas of thermal springs.

Our research shows that the most of the invasive species concentrated in the Yelizovsky district (Fig. 2). This re- 


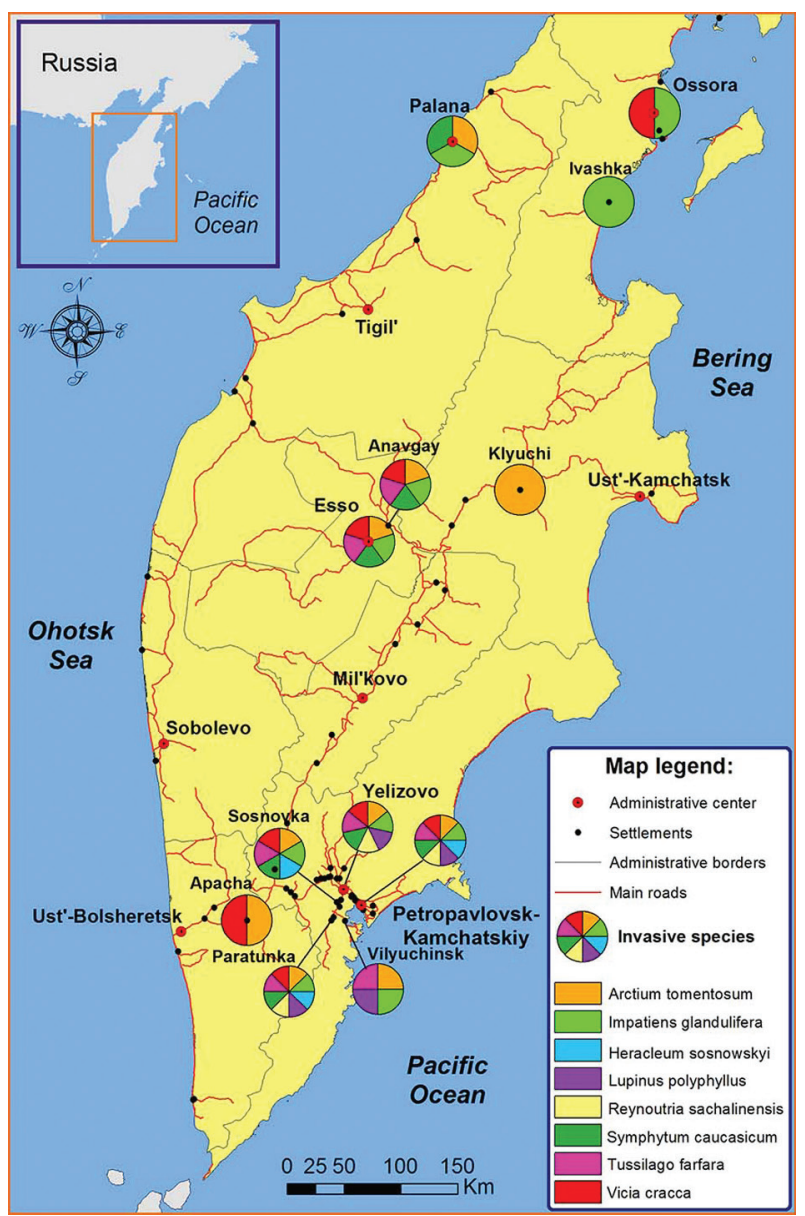

Figure 2 Distribution of invasive species in Kamchatka. Colored circles mark studied settlements.

gion has the most developed transport system, industry and agriculture. We found most of the species in urban areas of Petropavlovsk-Kamchatsky, Yelizovo and Vilyuchinsk. In the Bystrinsky district in Esso and Anavgay villages we found five invasive species. This may be due to good transport accessibility in comparison with other settlements under study. We observed the spread of a number of invasive species in the villages of North Kamchatka. Residents of these villages used Impatiens glandulifera and Symphytum caucasicum as ornamental plants. Other species occur in ruderal habitats. On the whole, moving to the north of the peninsula we observe that the number of invasive species is reduced, not only due to the lack of transport accessibility, but also due to more severe climatic conditions.

The investigation of synanthropic communities of urban vegetation in Petropavlovsk-Kamchatskiy allowed us to reveal introduced species of plants which adapted themselves to the urban habitats, became integrated with them and became the dominants of phytocenoses. The alien species Heracleum sosnowskyi Manden., Impatiens glandulifera Royle, Symphytum caucasicum Bieb., Lupinus polyphyllus Lindl., Tussilago farfara L. Vicia cracca L., Reynoutria sachalinensis (Fr. Schmidt) Nakai., Arctium tomentosum Mill. spread not only across ruderal habitats of the urban areas but also show a tendency to introduction and naturalization in natural habitats.
The investigation of invasion processes is especially important for such a unique region as Kamchatka. Aesthetically valuable landscapes attract lots of tourists whose activity may cause a chain reaction of mass spreading of species that are undesirable for the regional ecosystems. For this reason monitoring of invasive species condition is necessary as well as seeking ways of restraining their spread across the Kamchatka Krai.

\section{ACKNOWLEDGEMENTS}

The investigation of Larisa M. Abramova and Elizaveta A. Devyatova was supported by the Russian Foundation for Basic Research, grant № 16-34-50047 mol_nr - "Invasions of alien plant species in the Kamchatka region". The authors are grateful to Vadim E. Kirichenko for his help in the creation of the map.

\section{LITERATURE CITED}

Abramova, L.M. 2011a. Classification of communities with the participation of invasive species. I. Communities with the participation of the species of the genus Ambrosia $\mathrm{L}$. Rastitel'nost' Rossii 19:3-29 (in Russian). [Абрамова М.M. 2011. КАассификация сообществ с участием инвазивных вилов. І. Сообщества с участием вилов из рода $\mathrm{Am}$ brosia L. // Растительность России. № 19. С. 3-29].

Abramova, L.M. 2011b. The green plague: biological threat of alien plants. Ecologia i zhizn'3(112):70-74 (in Russian). [Абрамова А.М. 2011. Зеленая чума: биологическая угроза растений-чужеземцев // Экология и жизнь. №3 (112). C. 70-74].

Abramova, L.M. 2012. Expansion of invasive alien plant species in the Republic of Bashkortostan, the South Urals: analysis of causes and ecological consequences. Russian Journal of Ecology 43(5):352-357.

Abramova, L.M. 2015. Classification of communities with invasive species in the South Urals. II. Communities with the participation of the species of the genera Cyclachaena Fresen. and Xanthium L. Rastitel'nost' Rossii 27:24-39 (in Russian). [Абрамова А.M. 2015. Классификация сообществ с инвазивными видами на Южном Урале. II. Сообщества с участием видов из родов Cyclachaena Fresen. и Xanthium L. // Растительность России. № 27. C. 24-39].

Abramova, L.M., E.A. Devyatova, L. Strecker \& O.A. Chernyagina 2014. Characteristics of local populations of Heracleum sosnowskyi Manden. in Petropavlovsk-Kamchatsky (Russian Far East). Nauchnye vedomosti Belgorodskogo gosudarstvennogo universiteta 3(174):5-8 (in Russian). [Абрамова А.М., Аевятова Е.А., Штрекер $\Lambda .$, Чернягина О.А. 2014. К характеристике ценопопуляции борщевика Сосновского (Heracleum sosnowskyi Manden.) в городе Петропав овске-Камчатском (Российский АаАьний Восток) // Научные ведомости Белгородского госуАарственного университета. № 3 (174). С. 5-8].

Abramova, L.M., Ya.M. Golovanov \& S.V. Nurmieva 2013. Classification of communities with invasive species in the South Urals. Vestnik Kaqakhskogo Natsionalnogo Universiteta, Ser. ecologicheskaya 3(39):164-167 (in Russian). [Абрамова А.М., Голованов Я.М., Нурмиева С.В. 2013. Сообщества с инвазивными вилами растений на Южном Урале / / Вестник Казахского НУ. Сер. экологическая. № 3(39). C. 164-167].

Abramova, L.M \& O.N. Anufriev 2008. Aggressive neophytes of the Republic of Bashkortostan: biological threat. Vestnik Akademii Nauk Respubloki Bashkortostan 
4:34-43 (in Russian). [Абрамова М.М., Ануфриев О.Н. 2008. Агрессивные неофиты Республики Башкортостан: биологическая угроза // Вестник АН РБ. № 4. C. 34-43].

Ageeva, A.M. \& T.B. Silaeva 2012. Materials for the Black Book of Mordovia Republic. In: Problems of the study of adventitious and synanthropic floras of Russia and the CIS countries. Materials of the IV International conf. Izhevsk, pp. 185-187 (in Russian). [Агеева А.М., Силаева Т.Б. 2012. Материалы Аля Черной книги Республики Мордовия // Проблемы изучения аАвентивной и синантропной флор России и стран ближнего зарубежья. Матер. IV Междунар. конф. Ижевск. С. 185-187].

Anačkov, G.T., M.M. Rat, B.D. Radak, R.S. Igić, D.M. Vukov, M.M. Rućando \& M.M. Krstivojević 2013. Alien invasive neophytes of the southeastern part of the Pannonian Plain. Central European Journal of Biology 8(10): 1032-1043.

Arepjeva, L.A. 2015. Synanthropic vegetation of the city of Kursk. Kursk State University, Kursk, 203 pp. (in Russian). [Apeпьева А.А. 2015. Синантропная растительность гороАа Курска. Курск: Курский гос. ун-т, 203 с.].

Baranova, O.G. \& E.N. Bralgina 2015. Invasive plants in the flora of the Republic of Udmurtia. Vestnik Udmurtskogo Universiteta 25(2):31-35 (in Russian). [Баранова О.Г., Бралгина Е.Н. 2015. Инвазионные растения во флоре УАмуртской Республики // Вестник УАмуртского унта. Т. 25, вып. 2. С. 31-35].

Braun-Blanquet, J. 1964. Pflanzensociologie. Grundzuge der Vegetationskunde. 3 Aufl. Wien-New-York: Springer Verlag, 865 pp.

Bulokhov, A.D. \& A.V. Kharin 2008. Vegetation cover of Bryansk and its suburbs (syntaxonomy and monitoring). Publ. Office of BSU, Bryansk, 310 pp. (in Russian). [Булохов A.A., Харин А.В. 2008. Растительный покров Брянска и его пригородной зоны (синтаксономия и мониторинг). Брянск: РИО БГУ. 310 с.]

Bulokhov, A.D., Yu.A. Kljuev \& N.N. Panasenko 2011. Neophytes and their communities in Bryansk region. Botanicheskii Zhurnal 96(5):606-621 (in Russian). [Булохов А.А., КАюев Ю.А., Панасенко Н.Н. 2011. Неофиты и их сообщества в Брянской области // Ботанический журнал. Т. 96, № 5. С. 606-621].

Cherepanov, S.K. 1995. Vascular plants of Russia and adjacent states (former USSR). Mir i Sem'ya, Saint-Petersburg, 992 pp. (in Russian). [Черепанов С.К. 1995. Сосудистые растения России и сопредельных государств (в пределах бывшего СССР). СПб: Мир и Семья, 992 с.].

Chernyagina, O.A. \& L. Strecker 2012. Invasive species in the flora of Kamchatka. Estestvennye $i$ Tekbnicheskie Nauki 6(62): 150-152 (in Russian). [Чернягина O.А., Штрекер А. 2012. Инвазивные виды во флоре Камчатки / / Естественные и технические науки. № 6 (62). С. 150152].

Chernyagina, O.A., L. Strecker \& E.A. Devyatova 2013. New adventitious species in the flora of the Kamchatka peninsula. In: Conservation of biodiversity of Kamchatke and adjacent seas: reports of the XIV International Scientific Conference. Kamchatpress, Petropavlovsk-Kamchatsky, pp. 123-126 (in Russian). [Чернягина O.А., Штрекер $\Lambda . B .$, Аевятова Е.А. 2013. Новые адвентивные виды во флоре полуострова Камчатка // Сохранение биоразнообразия Камчатки и прилегающих морей: тезисы докладов XIV межАународной научной конфе-

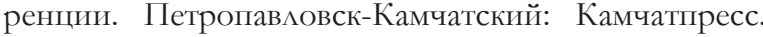
C. 123-126].

Chernyagina, O.A., L. Strecker \& E.A. Devyatova 2014.
Adventitious species in the flora of the Kamchatka peninsula. In: Conservation of biodiversity of Kamchatka and adjacent seas: reports of the XIV International Scientific Conference. Kamchatpress, Petropavlovsk-Kamchatsky, pp. 113-121 (in Russian). [Чернягина O.А., Штрекер А.В., Аевятова Е.А. 2014. ААвентивные виды во флоре помуострова Камчатка / / Сохранение биоразнообразия Камчатки и прилегающих морей: доклады XIV межАународной научной конференции. ПетропавловскКамчатский : Камчатпресс. С. 113-121].

Devyatova, E.A., O.A. Chernyagina \& L.M. Abramova 2015. Adventitious faction of the flora of Petropavlovsk-Kamchatskiy city. Izvestiya Ufimskogo nauchnogo tsentra 3:43-48 (in Russian). [Аевятова Е.А., Чернягина O.А., Абрамова А.М. 2015. ААвентивная фракция флоры города Петропавловска-Камчатского // Известия У фимского научного центра РАН, вып. 3. С. 43-48].

Dgebuadze, Yu.Yu. 2014. Alien species in Holarctic region: some results and prospects of investigation. Rossiiskii Zhurnal Biologicheskikh Invazii 7(1):2-8 (in Russian). [Агебуадзе Ю.Ю. 2014. Чужеродные виды в Голарктике: некоторые результаты и перспективы исследований // Российский журнал биомогических инвазий. Т. 7, № 1. С. 2-8].

Di Castri, F., A.J. Hansen \& M. Debussche (eds.) 1990. Biological invasions in Europe and the Mediterranean Basin. Kluwer Academic Publishers, Dordrecht, 428 pp.

Didham, R.K., J.M. Tylianakis, M.A. Hutchinson, R.M. Ewers \& N.J. Gemmell 2005. Are invasive species the drivers of ecological change? Trends in Ecology \& Evolution 20(9): 470-474.

Ebel, A.L., T.O. Strelnikova, A.N. Kupriyanov, O.A. Anenkhonov, E.S. Ankipovich, E.M. Antipova, A.V. Verkhozina et al. 2014. Invasive and potentially invasive species of Siberia. Byuleten' Glavnogo Botanicheskogo Sada 1:52-62 (in Russian). [Эбель А.А., Стрельникова Т.О., Куприянов А.Н., Аненхонов О.А., Анкипович Е.С., Антипова Е.М., Верхозина А.В. и Ар. 2014. Инвазионные и потенциально инвазионные виды Сибири / / Бюлметень ГАавного ботанического сада. № 1. С. 52-62].

Engelkes, T. \& N.J. Mills 2013. A fast-track for invasion: invasive plants promote the performance of an invasive herbivore. Biological Invasions 15:101-111.

Falinski, I.B. 1998. Invasive alien plants and vegetation dynamics. In: Plant Invasions: Ecological Mechanisms and Human Responses. Blackhuys, Leiden, pp. 3-22.

Fedorchenko, A.P. 1971. Some materials concerning the study of weedy plants of Kamchatka agricultural areas. In: Biological Resources of the terrestrial area in the north of the Far East. Vladivostok, pp. 180-185. (in Russian). [ФеАopченко А.П. 1971. Некоторые материалы к изучению сорной растительности земледельческих районов Камчатки // Биологические ресурсы суши Севера Аальнего Востока. ВАадивосток. С. 180-185].

Fukuda, T., A.A. Taran, H. Sato, Y. Kato \& H. Takahashi 2014. Alien plants collected or confirmed on the islands of Shikotan, Kunashir and Iturup on the 2009-2012 Botanical Expeditions. Biodiversity and Biogeography of the Kuril Islands and Sakhalin 4:8-26.

Golovanov, Ya.M. \& L.M. Abramova 2012. The flora of the city of Salavat (the Republic of Bashkortostan) III. Synanthropic flora (Bidentetea tripartitae, Stellarietea mediae and Artemisietea vulgaris classes). Rastitel'nost' Rossii 22:34 65 (in Russian). [Голованов Я.М., Абрамова А.М. 2012. Растительность города Салавата (Республика Башкортостан). III. Синантропная растительность (классы Bidentetea tripartitae, Stellarietea mediae и Artemisietea vulgaris) // Растительность России. № 22. С. 
34-65].

Gurevitch, J. \& D.K. Padilla 2004. Are invasive species a major cause of extinctions? Trends in Ecology \& Evolution $19(9): 470-474$.

Hennekens, S.M. 1995. TURBO(VEG). Software package for input processing and presentation of plantsociological data. User's guide. IBN-DLO Wageningen et University of Lancaster, 70 pp.

Hulme, P.E. 2007. Biological invasions in Europe: drivers, pressures, states, impact and responses. In: Biodiversity under threat, Cambridge, pp. 56-80.

Johnstone, I.M. 1986. Plant invasion windows: a time-based classification of invasion potential. Biological Reviews 61(4): 369-394.

Kharkevich, S.S. (ed.) 1985-1996. Vascular plants of the Soviet Far East, vol. 1-8. Nauka, Leningrad, Saint-Petersburg (in Russian). [Сосудистые растения советского АаАьнего Востока. / отв. реА. С.С. Харкевич. А.: Наука, 19851996. T. 1-8.].

Kharkevich, S.S. \& S.K. Cherepanov (eds.) 1981. A field guide to vascular plants of Kamchatka region. Nauka, Moscow, 412 pp. (in Russian). [Определитель сосудистых растений Камчатской об̆асти / пол. реА. С.С. Харкевича и С.К. Черепанова. М.: Наука, 1981. 412 с.]

King, V.M. \& R.D. Sargent 2012. Presence of an invasive plant species alters pollinator visitation to a native. Biological Invasions 14:1809-1818.

Komarov, V.L. 1954 Travelling in Kamchatka in 1908-1909s. Selected works. Vol. 6. Izdatel'stvo AN SSSR, Moscow, Leningrad, 528 pp. (in Russian). [Комаров B.ム. 1954. Путешествие по Камчатке в 1908-1909 гг. / Избр. соч. М.; А.: ИзА-во АН СССР. Т. 6. 528 с.]

Kondratyuk, V.I. 1983. The climate of Petropavlovsk-Kamchatsky. Gidrometeoizdat, Leningrad, 167 pp. (in Russian). [Кондратюк В.И. 1983. КАимат Петропавцовска-Камчатского. А.: Гидрометеоиздат. 167 с.].

Kopečky, K \& S. Hejny 1974. A new approach to the classification of antropogenic plant communities. Vegetatio 29:17-20.

Kowarik, I. \& U. Starfinger 2003. Biologische Invasionen. Neophyten und Neozoen in Mitteleuropa. Ulmer, Stuttgart, 380 pp.

Lonsdale, W.M. 1999. Global patterns of plant invasions and the concept of invisibility. Ecology 80(5):1522-1536.

Panasenko, N.N., L.N. Anishchenko \& Yu.G. Potsepay 2013. New data of invasive plants communities in Bryansk region. Bulleten' Moskovskogo Obshchestva Ispytateley Prirody. Biological Series 118(1):73-80 (in Russian). ППанасенко Н.Н., Анищенко А.Н., Поцепай Ю.Г. 2013. Новые сведения о сообществах инвазионных видов в Брянской области // Бюлметень Московского общества испытателей природы. ОтАел биологический. Т. 118, № 1. С. 73-80].

Panasenko N.N., I.M. Ivenkova \& E.P. Eliseenko 2012. Communities of neophytes in Bryansk Region. Rossiiskiy Zhurnal Biologicheskikh Invarii 2(16): 105-114 (in Russian). Панасенко Н.Н., Ивенкова И.М., Елисеенко Е.П. Сообщества неофитов в Брянской области // Российский журнал биологических инвазий. № 2 (16). C. 105-114].

Parker, I.M., D. Simberloff, W.M. Londfale, M. Goodell, P.M. Kareiva, M.N. Williamson, B. Von Holle et al. 1999. Impact: toward a framework for understanding the ecological effects of invaders. Biological Invasions 1:3-19.

Pyšek, P., J. Pergl, J. Sádlo, J. Wild \& M. Chytrý 2012. Plant invasions in the Czech Republic: current state, introduc- tion dynamics, invasive species and invaded habitats. Preslia 84(3):575-629.

Pyšek P., K. Prach \& B. Mandak 1998. Invasions of alien plants into habitats of Central European landscape: An historical pattern. In: Plant Invasion: Ecological mechanisms and Human Responses. Blackhuys, Leiden, pp. 23-32.

Pyšek, P., D.M. Richardson, M. Rejmanek, G.L. Webster, M. Williamson \& J. Kirschner 2004. Alien plants in checklists and floras: towards better communication between taxonomists and ecologists. Taxon 53(1):131-143.

Richardson, D.M., P. Pyšek, M. Rejmanek, M.G. Barbour, F.D. Panetta \& C.J. West 2000. Naturalization and invasion of alien plants: concepts and definitions. Diversity and distributions 6(2):93-107.

Sagalaev, V.A. 2013. Of the inventory of invasive species of the flora of Volgograd region. Vestnik Tverskogo Gosudarstvennogo Universiteta 32(31):102-105 (in Russian). [Сагалаев В.А. 2013. К инвентаризации инвазивных видов флоры Волгоградской области // Вестник Тверского гос. ун-та. Т. 32, № 31. С. 102-105.]

Silaeva, T.B. 2011. Alien species of the flora in the basin of the Sura River. Rossiiskii Zhurnal Biologicheskikh Invazii 4(3): 15-23 (in Russian). [Силаева Т.Б. 2011. Чужеродные виды флоры в бассейне реки Суры // Российский журнац биологических инвазий. Т. 4, № 3. С. 15-23].

Starodubtseva, E.A., O.V. Morozova \& A.Ya. Grigoryevskava 2014. Materials to the "Black Book of Voronezh region". Rossiiskii Zhurnal Biologicheskikh Invazii 2:133149 (in Russian). [Стародубцева Е.A., Морозова О.В., Григорьевская А.Я. 2014. Материалы к «Черной книге Воронежской области» // Российский журнац биомогических инвазий. № 2. С. 133-149].

Thompson, J.D. 1991. The biology of an invasive plant. Bioscience 41(6):393-401.

Tichy, L. 2002. JUICE, software for vegetation classification. Journal of Vegetation Science 13:451-453.

Tilman, D. 1997. Community invasibility, recruitment limitation, and grassland biodiversity. Ecology 78(1):81-92.

Tremasova, N.A., E.A. Borisova \& M.A. Borisova 2012. Invasive plant species of Yaroslavskaya region. Yaroslavskii Pedagogicheskii Vestnik 3(1):103-111 (in Russian). 'Тремасова Н.А., Борисова М.А., Борисова Е.А. 2012. Инвазионные виАы растений Ярославской области // Ярославский педагогический вестник. Т.3, № 1. С. 103-111].

Tretiyakova, A.C. 2011. Invasive potential of adventitious species of the Middle Urals. Russian Journal of Biological Invasions 3:62-69 (in Russian). [Третьякова A.C. Инвазионный потенциал аАвентивных вилов Среднего Урала // Российский журнал биологических инвазий. 2011. № 3. С.62-69.]

Ulyanova, T.N. 1976. Weed and field flora of Kamchatka region. Botanicheskii Zhurnal 61(4):555-561 (in Russian). [У ской области // Ботанический журнал. Т. 61, №4. C. 555-561].

Ulyanova, T.N. 1982. Kamchatka Peninsula. In: Biology and ecology of weeds, pp. 281-284. Springer, The Netherlands.

Vinogradova, Yu.K., S.P. Majorov \& L.V. Khorun 2010. The Black Book of the flora of Russia's Temperate Zone: alien species of plants in ecosystems of Russia's Temperate Zone. GEOS, Moscow, 512 рp. (in Russian). ВВиноградова Ю.К., Майоров С.Р., Хорун А.В. 2010. Черная книга флоры Средней России: чужеродные виды растений в экосистемах Средней России. М.: ГЕОС. 512 с.]. 
Vinogradova, Yu.K., S.P. Majorov \& A.A. Notov 2011. The Black Book of the flora of Tverskaya region: alien species of plants in ecosystems of Tuerskaya region. KMK Scientific Press Ltd., Moscow, 292 pp. (in Russian). [Виноградова Ю.К., Майоров С.Р., Нотов А.А. 2011. Черная книга флоры Тверской области: чужеродные виды растений в экосистемах Тверского региона. М.: Товарищество научных изАаний КМК. 292 с.].

Vinogradova, Yu.K., T.V. Akatova, O.A. Anenkhonov, E.S. Ankipovich, E.M. Antipova, L.A. Antonova, V.E. Afanasyev et al. 2015. «Black-list» of invasive species of Russia. The problems of industrial botany in industrially developed regions. In: Materials of the 4th International Conference and Summary Sitting of the UNDP-GEF/the Ministry of Natural Resources of the Russian Federation. Project group on the issues of the introduction of innovational technologies into the practice of coal-mining enterprises. Kemerovo, pp. 68-72 (in Russian). [Виноградова Ю.К., Акатова T.В., Аненхонов О.А., Анкипович Е.С., Антипова Е.М., Антонова А.А., Афанасьев В.Е. и Ар. 2015. БАэкАист инвазионных растений России // Проблемы промышленной ботаники индустриально развитых регионов. Кемерово. С. 68-72]. 